\section{'Roots' in mixotrophic algae}

SIR - Macroalgae are thought to depend on absorption of nutrients from the water column because, unlike vascular plants, they lack root systems with which to exploit nutrient resources in substrata ${ }^{1}$. Here we show that the giant marine coenocyte, Caulerpa taxifolia, possesses a 'root system' containing endocellular bacteria which can take up inorganic phosphorus and organic nitrogen from substrata and translocate nutrient products to the photoassimilatory organs. The uptake of carbon, nitrogen and phosphorus from substrata can explain the alga's ability to proliferate in oligotrophic water.

Caulerpa taxifolia produces stolons, fronds and gravipositive rhizoids which mimic the organs of a vascular plant. The rhizoids penetrate substrata and attach to attachment releases mineral-bound nutrients such as inorganic phosphorus directly to the alga ( $a$ in the figure). The rhizoids can also take up dissolved amino acid. Twin-compartment incubation of rhizoids in ${ }^{14} \mathrm{C}$-valine-labelled sea water and mineral surfaces. Chemical action at sites of

attached stolon and fronds in unlabelled sea water demonstrates significant uptake and translocation of ${ }^{14} \mathrm{C}$ from rhizoids to stolon and fronds ( $b$ in the figure). Previous work has shown that $\mathrm{NH}_{4}^{+}$can be absorbed by the rhizoids of $C$. cupressoides $^{2}$. Uptake of nutrients from substrata explains why: neither tissue nutrient content nor photosynthetic rate is correlated with seawater nutrient concentration ${ }^{3}$; seasonal changes in alkaline phosphatase activity are correlated with productivity and not seawater $\left[\mathrm{PO}_{4}^{3-}\right]$ (ref. 3), and elevation of seawater $\left[\mathrm{PO}_{4}^{3-}\right]$ does not inhibit alkaline phosphatase activity ${ }^{3}$, as occurs in other marine algae $^{4}$. These data indicate that nutrient uptake from the water column is subordinate to uptake from substrata.

Mixed bacteria coat the outer surfaces of the rhizoids, whereas large numbers of bacterial rods $\left(10^{4}-10^{5} \mathrm{~mm}^{-3}\right)$ exist in the cytoplasm. We isolated several different bacteria from cytoplasmic fluids aspirated from the rhizoids and cultured two Gramnegative, polarly flagellated, aerobic bacteria, with differing urease activity (A and
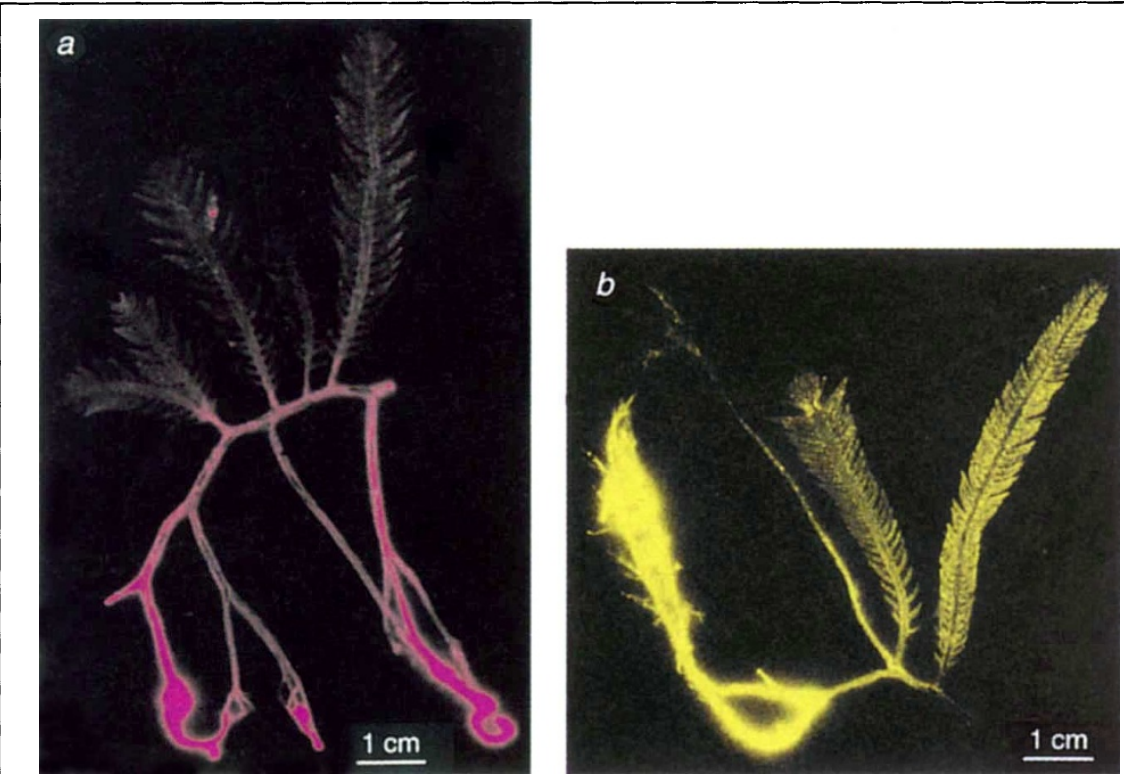

Autoradiographs demonstrating uptake of inorganic and organic nutrients by the rhizoids of $C$. taxifolia and their subsequent translocation to the photoassimilatory stolons and fronds. $a$, We grew test and control samples of $C$. taxifolia adjacent to one another for 7 days in flow-throw aquaria containing a 1-cm-deep, aerated bed of coarse $\mathrm{CaCO}_{3}$ sand (particle size 3-5 mm) labelled with a surface precipitate of ${ }^{33}$-apatite $\left(8.9 \mathrm{kBq} \mathrm{cm}^{-3}\right.$ substrate). We prepared the precipitate by agitating the sand grains for $6 \mathrm{~h}$ in a minimal volume of sea water containing $\mathrm{H}_{3}{ }^{33} \mathrm{PO}_{4}^{3-}$; we removed non-precipitated ${ }^{33} \mathrm{P}$ by flushing $(6 \mathrm{~h})$. We grew rhizoids of the test samples for a 7-day period until they had penetrated and attached to the substratum; we prevented rhizoids of control samples from making contact with the substratum. We then removed samples, rinsed them in fresh sea water, freed them of adhering sand grains, and pressed, dried and autoradiographed them. Test samples showed strong uptake of ${ }^{33} \mathrm{P}$ by the rhizoids and translocation of ${ }^{33} \mathrm{P}$ to the photoassimilatory parts, whereas control samples failed to produce an image on the autoradiographic film plate. $b$, We incubated rhizoids in sea water containing ${ }^{14} \mathrm{C}$-valine $\left(11.1 \mathrm{kBq} \mathrm{ml}{ }^{-1}\right)$ in one half of a slotted, twin-compartment, incubation vessel that allowed adjoining stolon and fronds to be incubated simultaneously in unlabelled sea water. Communication between the two incubation compartments (other than through the algal siphon) was prevented by sealing the junction between them with Vaseline, and gaseous exchange of respired ${ }^{14} \mathrm{CO}_{2}$ was prevented by capping the rhizoid compartment. Significant uptake of ${ }^{14} \mathrm{C}$ valine by the rhizoids, and translocation of ${ }^{14} \mathrm{C}$ to the stolon and fronds, occurred after $20 \mathrm{~h}$.
B). The $16 \mathrm{~S}$ ribosomal RNA sequences of these organisms ${ }^{5}$ place bacterium $\mathrm{A}$, a halophile, close to unnamed species of Rhodopseudomonas in the Agrobacterium-Rhizobium group of branch- $\alpha$ proteobacteria, and bacterium $\mathbf{B}$ in the fluorescent Pseudomonas group of branch- $\gamma$ proteobacteria $^{6}$. Bacterium A carries the nifH gene, which encodes nitrogenase production ${ }^{7}$. A Rhodopseudomonas-like bacterium with the potential to fix $\mathrm{N}_{2}$ in the rhizoids of an alga has not been reported.

Caulerpa taxifolia has recently proliferated in the northwest Mediterranean on substrata that are heavily enriched in organic matter, largely anoxic, perfused with hydrogen sulphide and contaminated with precipitated inorganic phosphorus. Oxygen deficits in rhizoids rooted in anoxic substrata could support $\mathrm{N}_{2}$ fixation ${ }^{8,9}$, thus accelerating decomposition of high $\mathrm{C}: \mathrm{N}$ macrophyte vegetation ${ }^{8}$ and hence nutrient supply to the alga. Removal of sulphide by a Rhodopseudomonas-like bacterium ${ }^{10}$ could give the alga a further advantage by protecting its rhizoids. Catabolism of organic substrates by endocellular and surface-borne heterotrophs could supply $\mathrm{CO}_{2}$ for photosynthesis and partially explain the highly negative $\delta^{13} \mathrm{C}$ tissue values $(<-30 \%)$ reported in other Caulerpa spp. ${ }^{11}$.

Further research must establish how the alga and bacteria interact, whether $\mathrm{N}_{2}$ fixation occurs, and the chemical mechanism by which inorganic phosphorus is acquired by the rhizoids. Our results show that the rhizoids of $C$. taxifolia function as 'roots' and can derive organic carbon and nitrogen, and inorganic phosphorus, directly from substrata. Rhizoid uptake of nutrients provides a physiological explanation for the success of siphonaceous green algae in oligotrophic tropical waters and the recent prolific development of $C$. taxifolia on eutrophic substrata in the northwest Mediterranean.

J. R. M. Chisholm ${ }^{\star}$, C. Dauga ${ }^{\dagger}$

E. Ageron ${ }^{\dagger}$, P. A. D. Grimont ${ }^{\dagger}$

J. M. Jaubert

* Unité des Entérobactéries,

Unité 386 INSERM, Institut Pasteur,

75724 Paris Cedex 15, France

†Observatoire Océanologique Européen,

Centre Scientifique de Monaco,

MC 98000 Principality of Monaco

1. Hanisak, M. D. in Nitrogen in the Marine Environment (eds Carpenter, E. J. \& Capone, D. G.) 699-730

(Academic, New York, 1983)

2. Williams, S. L. Limnol. Oceanogr. 29, 374-379 (1984)

3. Delgado, O. et al. Bot. Mar. 39, 61-67 (1996).

4. Delgado, O. \& Lapointe, B. E. Coral Reefs 13, 151-161 (1994).

Dauga, C. et al. Res. Microbiol. 144, 35-46 (1993)

6. Maidak, B. L. et al. Nucleic Acids Res. 22, 3485-3487 (1994).

7. Zehr, J. P. \& Reynolds, L. A. Appl. envir. Microbiol. 55, 2522-2526 (1989)

8. Paerl, H. W. in Advances in Microbial Ecology Vol. II (ed. Marshall, K. C.) 305-337 (Plenum, New York, 1990).

9. Villbrandt, M., Krumbein, W. E. \& Stal, L. J. Kieler Meeresforsch. Sonderh. 8, 158-163 (1991).

10. Hansen, T. A. \& van Gemerden, H. Arch. Mikrobiol. 86 , 49-56 (1972)

11. Raven, J. A. et al. Mar. Ecol. Prog. Ser. 123, 193-205 (1995)

NATURE · VOL $381 \cdot 30$ MAY 1996 